\title{
AL-AWQAF
}

Jurnal Wakaf dan Ekonomi Islam

Vol. 13, No. 2, Tahun 2020

\section{Pendistribusian Dana Wakaf dengan Skema Conditional Cash Transfers (CCTs) sebagai Solusi atas Permasalahan Stunting di Indonesia}

\author{
Husnul Mirzal ${ }^{1}$, Muhammad Wicaksono Hasdyani Putra ${ }^{2}$ \\ ${ }^{1}$ Universitas Airlangga, Surabaya, husnul.mirzal-2019@feb.unair.ac.id \\ 2 Universitas Airlangga, Surabaya, hasdyani.putra@gmail.com
}

\begin{abstract}
Indonesia is one of the countries with a very high number of stunting sufferers, in addition to affecting physical conditions in the form of disproportionate growth and development, in the short term stunting will increase morbidity and mortality rates in children under five. In the medium term, it will cause a decline in intellectual and cognitive abilities, and in the long run it has the potential to reduce the quality of human resources and the problem of degenerative diseases in adulthood. As one of the philanthropic instruments in Islam, waqf has the potential to reduce the stunting rate in Indonesia, one way is to distribute waqf using Conditional Cash Transfers scheme. This study aims to offer conditional cash transfer as a scheme in distributing waqf funds to reduce stunting rates in Indonesia. This research uses qualitative methods with a library research approach The results of this study indicate that waqf can be distributed using the Conditional Cash Transfers scheme to reduce stunting rates by targeting participants who come from poor families who have pregnant women and toddlers, requiring recipients to commit to checking themselves into health facilities, providing waqf funds in the form of nutrition and proper sanitation facilities, and the entire implementation process is supervised by a competent supervisor. The results of this study are expected to be useful for related parties in their efforts to reduce stunting rates in Indonesia.
\end{abstract}

Keywords: Waqf, Stunting, Conditional Cash Transfers.

Abstrak: Indonesia merupakan salah satu negara dengan jumlah penderita stunting yang sangat tinggi. Selain memengaruhi kondisi fisik berupa tumbuh kembang yang tidak proporsional, dalam jangka pendek stunting akan meningkatkan angka morbiditas dan mortalitas pada balita; dalam jangka menengah akan menyebabkan menurunnya intelektualitas dan kemampuan kognitif; dan dalam jangka panjang berpotensi menurunkan kualitas sumberdaya manusia dan menimbulkan masalah penyakit degeneratif di usia dewasa. Sebagai salah satu instrumen filantropis dalam Islam, wakaf memiliki potensi untuk menurunkan angka stunting di Indonesia. Salah satu caranya adalah dengan mendistribusikan wakaf menggunakan skema Conditional Cash Transfers. Penelitian ini bertujuan untuk menawarkan skema Conditional Cash Transfers dalam pendistribusian dana wakaf untuk menurunkan angka stunting di Indonesia. Penelitian menggunakan metode kualitatif dengan pendekatan studi kepustakaan. Hasil penelitian ini menunjukkan bahwa wakaf dapat didistribusikan menggunakan skema Conditional Cash Transfers untuk menurunkan angka stunting dengan menargetkan peserta yang berasal dari keluarga miskin yang memiliki ibu hamil dan balita, mensyaratkan komitmen penerima untuk memeriksakan diri ke fasilitas kesehatan, pemberian dana wakaf dalam bentuk nutrisi dan fasilitas sanitasi yang layak serta seluruh proses implementasi tersebut diawasi 
oleh supervisor yang berkompeten. Hasil dari penelitian ini diharapkan bermanfaat bagi pihak terkait dalam upaya menurunkan angka stunting di Indonesia.

Kata Kunci: Wakaf, Stunting, Conditional Cash Transfers

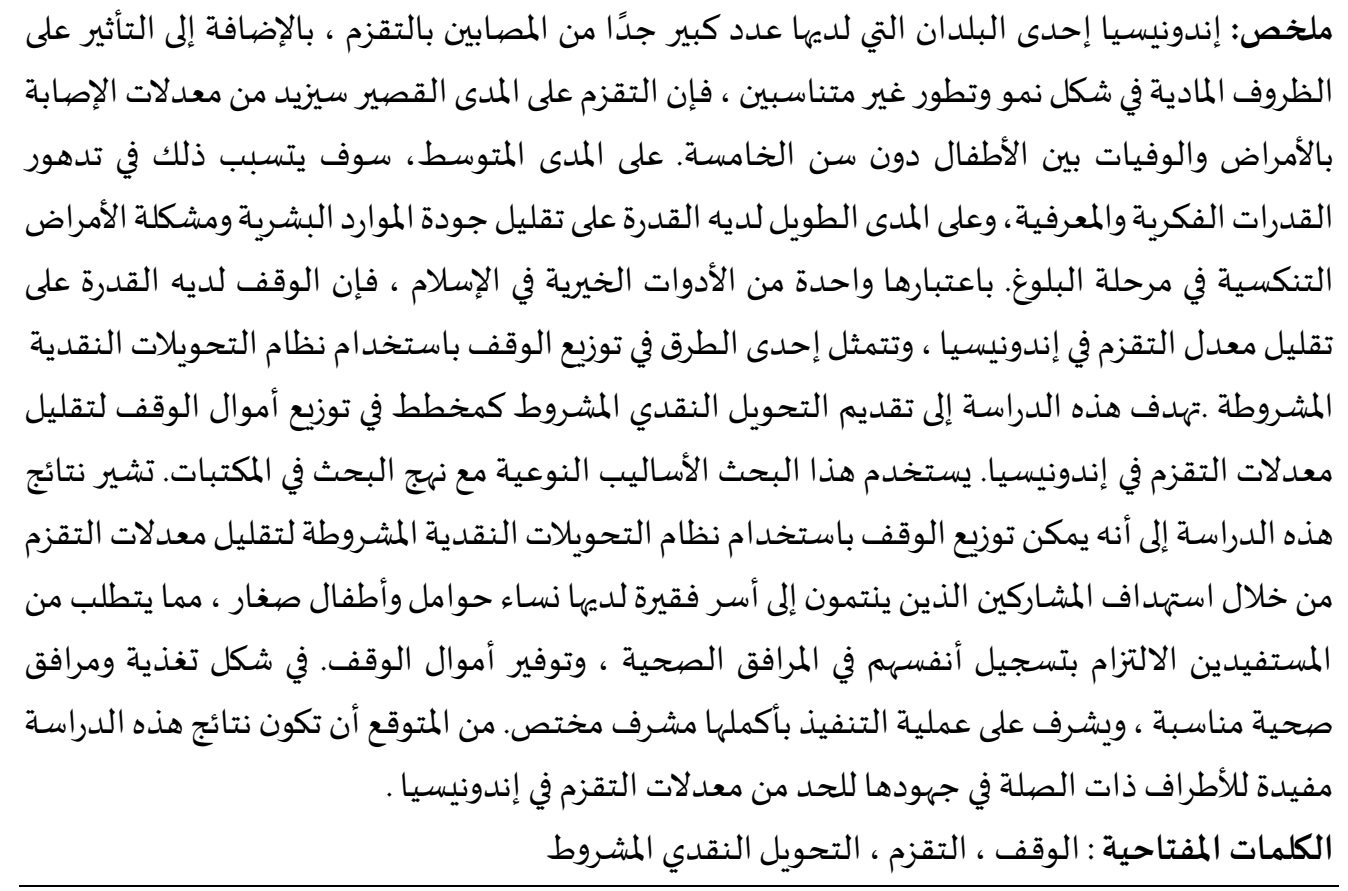

\section{Pendahuluan}

Permasalahan yang dialami oleh umat manusia semakin hari semakin kompleks, manusia dihadapkan dengan problematika kontemporer yang belum pernah dirasakan atau teridentifikasi sebelumnya baik masalah ekonomi, kesehatan maupun pendidikan. Sehingga aksi dan inovasi untuk menyelesaikan permasalahan yang muncul merupakan keniscayaan. Salah satu masalah kesehatan yang dihadapi oleh peradaban Indonesia kontemporer adalah masalah stunting, yaitu suatu keadaan tumbuh kembang anak yang tidak optimal yang ditandai dengan pertumbuhan tinggi badan yang tidak proporsional (Moniaga, Ohyver, Siregar, \& Yauwito, 2019). $30 \%$ dari total balita di Indonesia mengalami stunting, angka ini merupakan salah satu angka tertinggi di dunia, menempatkan Indonesia sejajar dengan Kamboja yang PDB perkapita tidak mencapai setengahnya Indonesia (Rizal \& van Doorslaer, 2019).

Masalah stunting tidak boleh dipahami sekadar masalah tumbuh kembang balita yang tidak optimal dilihat berdasarkan tinggi badan dari balita yang tidak proporsional. Melebihi itu stunting merupakan suatu gejala (symptom) yang muncul di permukaan diakibatkan masalah yang lebih serius dibelakangnya (Rizal \& van Doorslaer, 2019). Stunting ibarat fenomena gunung es (ice berg) dimana tampilan yang terlihat adalah bagian kecil dari realitas yang sebenarnya, atau gejala yang timbul adalah bagian kecil dari kompleksitas permasalahan. Angka stunting merupakan gambaran dari realitas kemiskinan yang terjadi di masyarakat yang tidak mampu memenuhi kebutuhan dasar berupa gizi yang seimbang bagi ibu hamil dan balita pada 1000 hari emas tumbuh kembang (Rizal \& van Doorslaer, 2019). Stunting juga menggambarkan kondisi sanitasi masyarakat, semakin buruk kualitas santitasi maka semakin meningkat angka stunting di suatu negara (Cameron et al., 2021). Stunting juga menggambarkan kondisi ketimpangan pendapatan masyarakat Indonesia, hal ini dapat dinilai dari fenomena peningkatan pertumbuhan ekonomi 
yang secara bersamaan diikuti oleh peningkatan balita penderita stunting, fenomena ini membuktikan bahwa pertumbuhan ekonomi hanya dirasakan oleh sebagian kelompok, tidak ikut dirasakan secara merata oleh seluruh masyarakat Indonesia (Rizal \& van Doorslaer, 2019).

Masalah stunting merupakan gambaran dari ketidakcukupan dan ketidaktepatan dari gizi dan nutrisi yang diperoleh oleh ibu hamil dan balita (Moniaga et al., 2019). Selain berpengaruh secara fisik berupa pertumbuhan tinggi badan yang tidak proporsional masalah ini dalam jangka panjang juga akan berpengaruh pada melambatnya pertumbuhan kemampuan kognitif. Selain itu kemampuan metabolisme juga akan terganggu. apabila problem tersebut terus terjadi secara masive dan berkepanjangan maka secara kolektif produktivitas dari suatu negara dimasa depan akan berkurang disebabkan memburuknya kualitas balita hari ini yang merupakan generasi penerus masa depan. Produktivitas yang menurun akan menimbulkan permasalahan sosial ekonomi yang lebih parah seperti kemiskinan dan pengangguran (Rizal \& van Doorslaer, 2019). Sebagian peneliti seperti N. K Aryastami \& Tarigan, (2017) membagi dampak stunting dalam tiga fase antara lain dalam jangka pendek stunting akan menyebabkan peningkatan angka kematian pada bayi/balita, dalam jangka menengah stunting menyebabkan menurunya intelektualitas dan kemampuan kognitif, dan dalam jangka panjang berpotensi menurunkan kualitas sumberdaya manusia dan masalah penyakit degeneratif di usia dewasa.

Islam sebagai agama yang rahmatan lil 'alamin memiliki tanggung jawab untuk menyelesaikan segala permasalahan yang dihadapi manusia, salah satunya adalah masalah stunting. Salah satu instrumen yang bisa dimanfaatkan untuk menyelesaikan permasalahan stunting adalah wakaf, hal ini karena sejarah telah membuktikan bahwa wakaf memiliki peran penting dalam membangun peradaban umat manusia khususnya umat Islam (Haneef, Muhammad, Pramanik, \& Mohammed, 2014) sebagai instrumen filantropis wakaf terbukti mampu menjadi solusi dari berbagai permasalahan sosial yang dihadapi manusia baik permasalahan ekonomi, kesehatan maupun pendidikan (Sukmana, 2020). Wakaf pertama kali diperkenalkan oleh Rasulullah ketika beliau melakukan hijrah dari Makkah ke Madinah, yaitu berupa wakaf tanah yang kemudian diatasnya dibangun Masjid Quba' (Sanusi \& Shafiai, 2015). Diawali praktik tersebut wakaf kemudian terus berkembang dalam lintasan sejarah umat Islam dan memberikan kontribusi nyata terhadap kehidupan umat manusia.

Untuk memaksimalkan potensi wakaf maka aplikasi wakaf tidak boleh dipahami secara sempit dan konservatif berupa kontribusi dalam bentuk properti saja seperti masjid, makam dan madrasah. Persepsi ini tentunya akan membatasi peran wakaf dalam menyelesaikan problematika umat. Padahal wakaf dapat diaplikasikan dalam berbagai inovasi, mengikuti tuntutan perkembangan zaman. Dengan semakin bervariasinya aplikasi wakaf maka kesempatan masyarakat untuk berwakaf semakin terbuka lebar dan potensi kontribusi wakaf terhadap sosial ekonomi tentunya juga semakin besar (Sanusi \& Shafiai, 2015).

Salah satu inovasi yang bisa dilakukan untuk mengoptimalkan peran wakaf dalam mengatasi masalah stunting adalah dengan mendistribusikan hasil pengelolaan dana wakaf menggunakan skema conditional cash transfers (CCTs). Hal ini karena skema tersebut telah terbukti perannya dalam menyelesaikan berbagai permasalahan sosial ekonomi di berbagai negara (Kabeer \& Waddington, 2015; Ranganathan \& Lagarde, 2012; Zulkhibri, 2016), termasuk menyelesaikan permasalahan stunting sebagaimana hasil penelitian yang dilakukan oleh Rizal \& van Doorslaer (2019), yang menyatakan bahwa salah satu program CCTs di Indonesia dengan nama Program 
Keluarga Harapan $(\mathrm{PKH})$ mampu menurunkan angka penderita stunting di Indonesia. Hal senada juga diungkapkan oleh Fernald, Gertler, \& Neufeld (2008) yang membuktikan efektivitas program CCTs di Mexico (Opportunides) dalam meningkatkan kesehatan dan tumbuh kembang anak-anak. Berdasarkan bukti dan potensi yang sangat baik dari skema CCTs dalam mengurangi masalah stunting maka penulis dalam penelitian ini tertarik untuk melakukan sebuah tawaran mekanisme penyaluran dana wakaf kepada manquf 'alaib menggunakan skema CCTs sehingga wakaf bisa berkontribusi dalam mengatasi masalah stunting di Indonesia. Sejauh bacaan penulis pada beberapa literature mengenai wakaf penulis belum menemukan penelitian sebelumnya yang mencoba menawarkan wakaf sebagai solusi atas permasalahan stunting di Indonesia. Begitu juga belum ada penelitian yang mencoba menawarkan teknis pendistribusian dana wakaf menggunakan skema CCTs. penelitian ini akan dipaparkan dalam sistematisasi berupa pendahuluan, landasan teoritis, metode penelitian, pembahasan dan penutup.

\section{Landasan Teoritis}

\section{Conditional Cash Transfers}

Conditional Cash Transfers (CCTs) adalah salah satu metode pemberdayaan sosial kemasyarakatan yang banyak dipraktikkan oleh berbagai negara di dunia. Secara sederhana CCTs adalah skema penyaluran bantuan sosial yang mempersyaratkan adanya timbal balik dari penerima bantuan sosial tesebut (Santana, Pais, \& Silva, 2013). Timbal balik yang dipersyaratkan bersifat wajib untuk dilaksanakan. Apabila tidak dipenuhi oleh peserta maka bantuan yang diberikan akan dihentikan (Zulkhibri, 2016). Ciri khas dari penyaluran bantuan ini adalah adanya persyaratan (conditionality) yang harus dipenuhi (Kabeer \& Waddington, 2015). Persyaratan tersebut umumnya adalah berupa komitmen oleh penerima untuk melakukan suatu aktivitas yang akan bermanfaat untuk pemberdayaan dirinya dan keluarganya (Son, 2008). Seperti persyaratan berupa kewajiban untuk bersekolah (Ferreira, Filmer, \& Schady, 2018), berhadir ke salah satu fasilitas kesehatan (Rahman \& Pallikadavath, 2018) dan mengikuti pembelajaran tentang pemberdayaan ekonomi (Mariano, 2020). Tujuan utama dari adanya CCTs adalah untuk memberdayakan masyarakat dengan cara mengeluarkan mereka dari berbagai permasalahan sosial, baik masalah ekonomi maupun kesehatan (Waziri, Zubir, Ibrahim, Bin, \& Bin, 2020; Zulkhibri, 2016).

Penyaluran dana sosial menggunakan CCTs pertama kali dilakukan oleh pemerintahan negara Mexico dengan nama Progresa (Barham \& Rowberry, 2013) pada tahun 1990 yang kemudian diikuti oleh Brazil dengan nama Bolsa Familia (Santana et al., 2013) dan Bangladesh (Son, 2008). CCTs sudah dipraktikkan di 35 negara dengan total 53 program di seluruh dunia (Zulkhibri, 2016). Negara yang berpartisipasi umumnya adalah negara-negara berkembang dengan pendapatan menengah kebawah seperti Kamboja, Indonesia, Filipina, Vietnam, Pakistan, Argentina, Bolivia, Chile, Colombia, Ecuador, Honduras, Jamaika, Paraguay, Panama dan lainlainnya (Son, 2008; Zulkhibri, 2016). Jumlah sesungguhnya diperkirakan lebih tinggi dari nominal diatas dan akan terus meningkat mengingat semakin meningkatkan permasalahan sosial yang dihadapi oleh masyarakat di seluruh dunia.

Sejauh ini pengimplementasian CCTs menunjukkan dampak yang sangat baik bagi perbaikan kualitas hidup masyarakat miskin dan masyarakat sangat miskin di berbagai negara (Fishbein 
\& Ajzen, 2005; Kabeer \& Waddington, 2015). Program ini terbukti mampu menurunkan angka kemiskinan dalam jangka panjang (Zulkhibri, 2016). Dari aspek pendidikan CCTs berkontribusi positif dalam menurunkan angka putus sekolah (Norbert Schady \& Maria Caridad Araujo, 2008; Schultz, 2004) meningkatkan angka kehadiran siswa ke sekolah (Attanasio et al., 2010; Cacciamali, Tatei, \& Batista, 2010; Dubois, de Janvry, \& Sadoulet, 2012; Ravallion \& Wodon, 2000), meningkatkan prestasi akademik dan angka keberlanjutan studi ke tingkat perguruan tinggi (Mill, Macours, Maluccio, \& Tejerina, 2020) serta menurunkan angka pekerja anak (Attanasio et al., 2010; Skoufias \& Parker, 2001). Pada sektor kesehatan pengimplementasian CCTs memberikan dampak positif dalam meningkatkan kualitas kesehatan para penerima bantuan (Pescarini et al., 2020), seperti mengurangi jumlah kematian pada ibu hamil dan balita (Ranganathan \& Lagarde, 2012), meningkatkan angka partisipasi pada vaksinasi rutin (Kusuma, Thabrany, Hidayat, \& Mcconnell, 2017), menurunkan angka obesitas (Charness, Gneezy, Org, \& Charness, 2008; Volpp et al., 2008), menurunkan angka kematian pada lansia (Barham \& Rowberry, 2013; Oliveira, Kassouf, \& Aquino, 2017) dan menurunkan angka perokok (Volpp et al., 2009). Manfaat dari CCTs ini sangat bervariasi antara satu negara dengan negara lainnya tergantung tujuan yang ingin dicapai oleh masing-masing negara, dan pada umumnya program ini berhasil dalam mencapai target yang diinginkan (Zulkhibri, 2016).

Implementasi CCTs diberbagai negara memiliki target yang berbeda-beda, tergantung permasalahan sosial yang sedang dihadapi oleh negara yang bersangkutan. Bagi negara Amerika Latin seperti Meksiko dan Colombia program ditargetkan pada pengurangan jumlah pekerja anak, angka putus sekolah, lansia terlantar dan kemiskinan (Dubois et al., 2012; Rawlings \& Rubio, 2005; Skoufias \& Parker, 2001) di Indonesia sendiri program ini menyasar problem kemiskinan, angka kematian ibu dan anak, lansia terlantar, balita stunting, capaian vaksinasi dan angka putus sekolah (Bappenas, 2008; Zulkhibri, 2016). Meskipun tujuan antar negara berbeda-beda namun pada umumnya tujuan tersebut berkisar pada pengurangan angka kemiskinan, perbaikan kondisi kesehatan, pendidikan dan perbaikan kualitas hidup para lansia. Selain dijalankan oleh pemerintahan negara, program ini juga diinisiasi oleh beberapa institusi international seperti bank pembangunan multilateral dan organisasi kemanusian non pemerintah (NGO) (Zulkhibri, 2016).

\section{Perkembangan Wakaf Kontemporer dan Kontribusinya terhadap Sektor Kesahatan}

Hakikat wakaf tidak dapat dipisahkan dari pembangunan. Secara historis, pengentasan kemiskinan merupakan salah satu sasaran utama wakaf (Hamber \& Haneef, 2017). Selain itu, pelayanan kesehatan, pendidikan dan pembangunan infrastruktur termasuk dalam daftar penerima utama tunjangan wakaf. Tren penargetan penghapusan kemiskinan dan inklusi sosial ekonomi melalui wakaf ditentukan oleh wakaf filantropi pertama dalam sejarah Islam yang dibuat oleh khalifah Umar r.a. pada tahun keenam hijrah (Abdullah, 2018). Aksinya berisi alokasi manfaat bagi orang miskin dan individu membutuhkan lainnya dalam masyarakat (Sukmana, 2020; Zakari, 2015).

Hebatnya, wakaf adalah lembaga sukarela berbasis syariah, yang diharapkan berfungsi sejalan dengan maqasid al-shariah (tujuan syariah yang lebih tinggi). Dalam konteks ini, perlu digarisbawahi bahwa karena kerangka SDGs memiliki banyak kesamaan dengan agenda pembangunan berbasis maqasid (Khan, 2015), maka lembaga wakaf dapat memainkan peran perantara dalam mewujudkan target bersama baik SDGs maupun tujuan pembangunan. 
maqasid al-shariah. Dengan demikian, dalam pencapaian SDGs khususnya di negara-negara mayoritas muslim, peran wakaf global yang diperkirakan bernilai \$ 1 triliun tentu sangat signifikan (Abdullah, 2018).

Wakaf yang berkembang di Indonesia idealnya seperti instrumen ekonomi lain (zakat infaq dan sedekah). Namun di Indonesia, wakaf sepenuhnya belum mampu menunjukkan dan memberikan kemanfaatannya secara optimal. Lembaga independen yang bertanggung jawab mengembangkan perwakafan di Indonesia atau sering disebut Badan Wakaf Indonesia (BWI) sudah mulai menjalankan fungsinya. Salah satu contohnya adalah melakukan pembekalan kepada para nazhir di Indonesia dengan pengetahuan terkait wakaf. Hal ini karena nazhir memiliki peran penting dalam pengelolaan wakaf yang menentukan sukses dan gagalnya aplikasi wakaf di suatu negara (Atabik, 2014).

Relevansi modern wakaf bergantung pada pendekatan kontekstual dan penerapan strategisnya. Secara teoritis, karena menjadi bentuk lembaga filantropi yang abadi, kerangka konseptual wakaf tidak diragukan lagi relevan di berbagai masyarakat dan yurisdiksi (Noordin, Haron, \& Kassim, n.d.). Namun, apakah kepraktisan maupun fungsionalitas wakaf sesuai dengan esensi kebutuhan sosial ekonomi modern adalah satu-satunya parameter untuk menimbang relevansi wakaf kontemporer. Pada prinsipnya, mungkin ada keseragaman yang hampir sama dalam kebutuhan sosio-ekonomi dasar masyarakat (Seprillina, Qurrata, Narmaditya, \& Hussain, 2019). Meskipun demikian, prioritas sosial mungkin berbeda di setiap negara dan yurisdiksi. Idealnya, pengentasan kemiskinan, pendidikan, perawatan kesehatan dan pembangunan infrastruktur adalah bidang publik yang secara intensif difokuskan serta pengeluaran filantropi dalam masyarakat tertentu (Khan, 2015). Oleh karena itu, relevansi wakaf modern akan dikonfirmasi jika lembaga wakaf tanggap terhadap kebutuhan pembangunan ini secara mendesak.

Sebagaimana ditegaskan sebelumnya, lembaga wakaf memiliki rekam jejak yang terbukti dalam kesejahteraan sosial dan pembangunan, dan paling cocok untuk menggurui tujuan yang dapat dilayani melalui filantropi (Seprillina et al., 2019; Usman, 2014). Waqf menggabungkan dan menampilkan semua apa dibutuhkan dalam lembaga filantropi yang ideal. Memiliki sejarah yang mulia, kerangka kerja yang fleksibel, agenda pembangunan, kapasitas keuangan, pendekatan pragmatisme, mekanisme keberlanjutan, paradigma berbasis nilai, karakter inklusif dan program yang komprehensif . Berdasarkan data yang ada, wakaf banyak negara Muslim dan non-Muslim seperti Indonesia dan India cukup memadai untuk mengisi gap yang ada pada anggaran publik yang ditargetkan untuk kesejahteraan umat Islam di negara-negara tersebut (Darus et al., 2017).

Wakaf produktif biasanya diberikan dalam bentuk tanah pertanian dan bangunan komersial yang dikelola sedemikian rupa untuk mendatangkan keuntungan yang sebagian hasilnya digunakan untuk membiayai berbagai kegiatan. Oleh karena itu, dana wakaf merupakan sumber dana dari masyarakat untuk masyarakat. Artinya wakaf produktif tidak hanya berupa uang tunai yang dikelola tetapi juga berupa aset yang dapat dikelola oleh banyak orang dan hasilnya akan memberikan manfaat terutama bagi lingkungan sekitar. Pengelolaan wakaf produktif di Indonesia juga bisa meniru Malaysia dan Singapura. Di Malaysia tidak hanya penjualan saham yang dilakukan MAIS (Selangor), produksi obligasi juga dapat digunakan di dalam dan di luar 
penjualan properti wakaf yang memiliki imbal hasil lebih tinggi. Produksi Obligasi dilakukan oleh MUIS (Singapura) (Sanusi \& Shafiai, 2015).

Relevansi modern wakaf bergantung pada pendekatan kontekstual dan penerapan strategisnya. Secara teoritis, karena menjadi bentuk lembaga filantropi yang abadi, kerangka konseptual wakaf tidak diragukan lagi relevan di berbagai masyarakat dan yurisdiksi (Noordin et al., n.d.). Namun, apakah kepraktisan maupun fungsionalitas wakaf sesuai dengan esensi kebutuhan sosial ekonomi modern adalah satu-satunya parameter untuk menimbang relevansi wakaf kontemporer. Pada prinsipnya, mungkin ada keseragaman yang hampir sama dalam kebutuhan sosio-ekonomi dasar masyarakat (Seprillina et al., 2019). Meskipun demikian, prioritas sosial mungkin berbeda di setiap negara dan yurisdiksi. Idealnya, pengentasan kemiskinan, pendidikan, perawatan kesehatan dan pembangunan infrastruktur adalah bidang publik yang secara intensif difokuskan serta pengeluaran filantropi dalam masyarakat tertentu (Khan, 2015). Oleh karena itu, relevansi wakaf modern akan dikonfirmasi jika lembaga wakaf tanggap terhadap kebutuhan pembangunan ini secara mendesak.

Sebagaimana ditegaskan sebelumnya, lembaga wakaf memiliki rekam jejak yang terbukti dalam kesejahteraan sosial dan pembangunan, dan paling cocok untuk menggurui tujuan yang dapat dilayani melalui filantropi (Seprillina et al., 2019; Usman, 2014). Waqf menggabungkan dan menampilkan semua apa dibutuhkan dalam lembaga filantropi yang ideal. Memiliki sejarah yang mulia, kerangka kerja yang fleksibel, agenda pembangunan, kapasitas keuangan, pendekatan pragmatisme, mekanisme keberlanjutan, paradigma berbasis nilai, karakter inklusif dan program yang komprehensif . Berdasarkan data yang ada, wakaf banyak negara Muslim dan non-Muslim seperti Indonesia dan India cukup memadai untuk mengisi gap yang ada pada anggaran publik yang ditargetkan untuk kesejahteraan umat Islam di negara-negara tersebut (Darus et al., 2017).

Wakaf produktif biasanya diberikan dalam bentuk tanah pertanian dan bangunan komersial yang dikelola sedemikian rupa untuk mendatangkan keuntungan yang sebagian hasilnya digunakan untuk membiayai berbagai kegiatan. Oleh karena itu, dana wakaf merupakan sumber dana dari masyarakat untuk masyarakat. Artinya wakaf produktif tidak hanya berupa uang tunai yang dikelola tetapi juga berupa aset yang dapat dikelola oleh banyak orang dan hasilnya akan memberikan manfaat terutama bagi lingkungan sekitar. Pengelolaan wakaf produktif di Indonesia juga bisa meniru Malaysia dan Singapura. Di Malaysia tidak hanya penjualan saham yang dilakukan MAIS (Selangor), produksi obligasi juga dapat digunakan di dalam dan di luar penjualan properti wakaf yang memiliki imbal hasil lebih tinggi. Produksi Obligasi dilakukan oleh MUIS (Singapura) (Sanusi \& Shafiai, 2015).

Selanjutnya, contoh wakaf produktif yang banyak menarik perhatian saat ini adalah wakaf produktif yang membiayai yayasan. Yayasan bisa berupa pesantren, tempat pendidikan bahkan rumah sakit. Di Malang Jawa Timur, jenis wakaf produktif diberikan dalam bentuk yayasan rumah sakit yang pertama kali digagas oleh Yayasan Universitas Islam Malang (Unisma). Dengan menggunakan wakaf produktif dapat memberikan manfaat positif bagi lingkungan sekitar. Dampak positif RS Unisma akan membentuk dan mendukung pemberdayaan keadaan baik dari segi ekonomi maupun sosial (Seprillina et al., 2019). Dengan adanya programprogram tersebut diharapkan dapat meningkatkan kesejahteraan masyarakat. Selain itu, 
pemberdayaan masyarakat juga diperkirakan mengurangi tingkat kemiskinan serta pengangguran saat itu bisa dilakukan secara maksimal.

Beberapa aset wakaf pun ada yang mengalokasikan dana kebermanfaatan wakaf mereka terhadap bidang kesehatan seperti yang dilakukan oleh Masjid Agung Semarang yang terletak di sebelah Pasar Johar Kota Semarang. Dalam bidang kesehatan, tanah bandha wakaf dikelola dan dikembangkan dalam bentuk Klinik Masjid Agung Semarang dan Klinik Masjid Agung Jawa Tengah (Usman, 2014). Keduanya dikelola secara terpisah dan menginduk pada organisasi atau manajemen yang berbeda namun memiliki persamaan utama, yaitu lokasi berdirinya kedua klinik tersebut merupakan tanah wakaf dan keduanya dirintis dan didanai oleh pengelola masjid wakaf.

Dari beberapa penjelasan diatas menujukkan bahwa perkembangan wakaf di berbagai sektor sangat memungkinkan membantu menyelesaikan beberapa permasalahan ummat khususnya pada bidang kesehatan. Pengembangan aset wakaf tidak hanya dalam bentuk tanah, tetapi juga dapat mensupport pembangunan masyarakan menuju masyarakat madani dengan pengembangan pada sektor kesehatan maupun pemanfaatan dana tersebut. Dengan munculnya banyak jenis wakaf dalam bidang kesehatan maupun pemanfaatan dana kebermanfaatan wakaf, tidak menutup kemungkinan tujuan dicetuskannya wakaf akan segera tercapai dan menunjukkan bahwa Islam tidak hanya membahas sisi amalan maupun ibadah, tetapi juga kesejahteraan masyarakat.

Tujuan dari wakaf yang selaras dengan pengembangan SDGs saat ini, sangat memungkinkan berjalan beriringan dalam membentuk kualitas masyarakat menjadi masyarakat yang sejahtera. Khususnya penyelesaian terhadap problematika stunting di Indonesia maupun internasional sangat memungkinkan menurun drastis apabila wakaf dapat berjalan beriringan dengan program pemerintah saat ini.

\section{Metode Penelitian}

Penelitian ini menggunakan metode kualitatif dengan pendekatan penelitian literatur kepustakaan (library research) atau dalam istilah Tight (2019) disebut sebagai Documentary Research. Documentary Research adalah jenis pendekatan dalam penelitian yang menjadikan dokumen atau literatur kepustakaan sebagai objek penelitian (Soeherman, 2019). Dokumen tersebut adalah segala apapun yang mengandung informasi baik berupa tulisan, gambar, foto, rekaman dan video yang dibutuhkan oleh peneliti untuk mengungkap tujuan penelitian (Tight, 2019). Pemilihan pendekatan library research dalam penelitian ini karena peneliti hendak menggali beberapa metode penyaluran dana sosial menggunakan skema Conditional Cash Transfers (CCTs) dalam beberapa literature kepustakaan yang kemudian dijadikan dasar dalam menawarkan model penyaluran wakaf menggunakan skema CCTs tersebut untuk mengatasi permasalahan stunting di Indonesia. Jenis data adalah berupa data sekunder yang didapatkan dari berbagai literatur ilmiah yang berkenaan dengan wakaf, stunting dan CCTs seperti Jurnal, Buku, Working Paper dan sejenisnya.

\section{Hasil dan Pembahasan}

Untuk mendistribusikan dana hasil pengelolaan pokok dari wakaf kepada manquf 'alaih dalam skema CCTs maka ada beberapa hal yang harus diperhatikan terutama berkenaan dengan ketentuan dan cara implementasi dari CCTs itu sendiri yang tentunya berbeda dengan 
mekanisme pendistribusian yang dilakukan secara konvensional (Son, 2008). Karena CCTs merupakan skema pendistribusian dari dana bantuan sosial kepada para penerima yang diikuti oleh persyaratan (conditional) tertentu yang harus dipenuhi oleh penerima (Kabeer \& Waddington, 2015) maka poin esensial yang harus diperhatikan terlebih dahulu adalah berkenaan dengan jenis persyaratan yang akan dibebankan kepada penerima, dalam kasus dana wakaf maka berupa persyaratan-persyaratan yang akan dibebankan kepada manquf alaih.

Tabel 1. Literatur yang menjadi sumber pembahasan dan temuannya terkait penyaluran dana sosial dengan skema CCT.

\begin{tabular}{|l|l|}
\hline Literatur & $\begin{array}{l}\text { Temuan riset terkait penyaluran dana sosial } \\
\text { dengan skema CCT }\end{array}$ \\
\hline Ravallion \& Wodon, 2000 & $\begin{array}{l}\text { Persyaratan yang ditetapkan dalam praktik CCT di } \\
\text { berbagai negara sangat variatif tergantung kepada } \\
\text { tujuan dari implementasi CCT tersebut. }\end{array}$ \\
\hline Santana et al., 2013 & $\begin{array}{l}\text { Pemerintah Meksiko dan Brazil mengimplementasikan } \\
\text { CCT dengan syarat para penerima atau anggota } \\
\text { keluarga penerima yang masih usia sekolah harus } \\
\text { terdaftar di salah satu lembaga pendidikan dan harus } \\
\text { memenuhi jumlah persentase kehadiran tertentu ke } \\
\text { sekolah. }\end{array}$ \\
\hline Rizal \& van Doorslaer, 2019 & $\begin{array}{l}\text { Dalam Program Keluarga Harapan (PKH) di } \\
\text { Indonesia, persyaratan yang ditetapkan bagi penerima } \\
\text { bantuan berupa kewajiban penerima untuk } \\
\text { memeriksakan kondisi kehamilan dan balita ke fasilitas } \\
\text { kesehatan (posyandu). }\end{array}$ \\
\hline Bantuan dari wakaf bisa disalurkan dalam bentuk \\
makanan dan minuman yang mengandung nutrisi- \\
nutrisi yang dibutuhkan oleh ibu hamil dan balita untuk \\
mencegah terjadinya stunting.
\end{tabular}

Persyaratan yang ditetapkan dalam praktik CCTs di berbagai negara sangat variatif tergantung kepada tujuan dari implementasi CCTs tersebut (Ravallion \& Wodon, 2000) yang tentunya didasari oleh latar belakang permasalahan yang dimiliki masing-masing negara (Santana et al., 
2013). Pada negara yang memiliki masalah dengan tingginya angka putus sekolah seperti Meksiko dan Brazil maka pemerintah akan mengimplementasikan CCTs dengan syarat para penerima atau anggota keluarga penerima yang masih usia sekolah harus terdaftar di salah satu lembaga pendidikan dan harus memenuhi jumlah persentase kehadiran tertentu ke sekolah (Santana et al., 2013), persyaratan ini bertujuan agar angka putus sekolah menurun dan para penerima bantuan terberdayakan dalam aspek pendidikan. Apabila masalah yang dihadapi berupa tingginya angka kematian ibu hamil dan balita seperti yang dialami Indonesia maka persyaratan yang ditetapkan adalah berupa kewajiban penerima untuk memeriksakan kondisi kehamilan dan balita ke fasilitas kesehatan (posyandu) (Rizal \& van Doorslaer, 2019). Persyaratan ini terkadang tidak tunggal diterapkan secara bersamaan apabila masalah yang ingin diselesaikan juga beragam (Zulkhibri, 2016). Seperti Indonesia yang mempersyaratkan komitmen terhadap kesehatan, pendidikan dan ekonomi secara bersamaan pada Program Keluarga Harapan (PKH).

Pendistribusian dana wakaf kepada manquf alaib memiliki tujuan untuk mengurangi angka stunting di Indonesia maka persyaratan yang harus dipenuhi oleh penerima adalah kewajiban untuk memeriksakan kondisi kehamilan dan tumbuh kembang balita ke fasilitas kesehatan dengan frekuensi dan persentase tertentu sesuai dengan ketentuan yang ditetapkan oleh otoritas kesehatan di Indonesia. Dengan pemenuhan kewajiban tersebut maka resiko balita mengalami stunting semakin berkurang (Fernald et al., 2008). Selain pada penetapan persyaratan yang harus dipenuhi oleh manquf 'alaih dana wakaf juga bisa disalurkan dalam bentuk makanan dan minuman yang mengandung nutrisi-nutrisi yang dibutuhkan oleh ibu hamil dan balita untuk mencegah terjadinya stunting, karena kekurangan asupun gizi dan nutrisi merupakan faktor utama terjadinya stunting (Nur Cahyadi et al., 2018). Selain dalam bentuk nutrisi bantuan dana wakaf juga bisa diberikan dalam bentuk fasilitas sanitasi yang layak karena sanitasi yang buruk memiliki korelasi pada peningkatan angka penderita stunting (Cameron et al., 2021).

Selain perihal conditionality yang diterapkan implementasi CCTs juga harus memperhatikan siapa para penerima yang akan mendapatkan bantuan dalam bentuk CCTs tersebut (Son, 2008). Penerapan di beberapa negara program ini biasanya menyasar kelompok masyarakat kategori miskin dan masyarakat sangat miskin, akan tetapi biasanya masyarakat dengan kategori sangat miskin lebih diprioritaskan hal ini berkaitan dengan skala prioritas penerima karena jumlah masyarakat miskin sangat banyak dengan dana yang terbatas (Son, 2008). Dalam implementasinya CCTs tidak hanya menyasar masyarakat miskin saja tetapi masyarakat miskin yang memenuhi syarat sebagai target penerima CCTs sesuai dengan tujuan implementasi dari CCTs tersebut (Santana et al., 2013), misalnya adalah masyarakat miskin yang memiliki balita dan anak yang masih berstatus sekolah, persyaratan memiliki balita dan anak umur wajib sekolah karena tujuan CCTs untuk menyelesaikan masalah yang berkaitan dengan angka putus sekolah dan kesehatan dan keselamatan ibu hamil dan balita. Berkenaan dengan implementasi dana wakaf untuk mengurangi angka stunting maka target dari para penerima (mauquf 'alaib) tersebut adalah para keluarga miskin yang dalam rumah tangga tersebut terdapat ibu hamil dan balita. Sehingga dana wakaf yang diberikan bisa tepat sasaran dalam rangka mengurangi angka stunting. 
Dalam menyukseskan penerapan CCTs pihak pelaksana biasanya menggunakan tenaga pendamping sosial (supervisor) masyarakat yang bertugas untuk memonitori bisnis proses pelaksanaan program CCTs (Muhtar, 2020; Nurwan \& Hasan, 2020). Fungsi dari adanya pendamping adalah untuk melaksanakan proses rekrutmen terhadap manquf 'alaih yang akan mendapatkan bantuan dana wakaf, pendamping bertugas untuk memastikan penerima dari dana wakaf tersebut sesuai dengan persyaratan yang telah ditetapkan sebelumnya yaitu manquf 'alaib dari keluarga miskin yang memiliki ibu hamil dan balita. Selain kesesuaian terhadap penerima para pendamping juga harus mengawasi para penerima bantuan untuk melaksanakan persyaratan yang telah ditetapkan sebelumnya yaitu berupa kewajiban untuk memeriksakan kehamilan dan kondisi tumbuh kembang balita ke fasilitas kesehatan dengan frekuensi dan nominal persentase tertentu (Bappenas, 2008). Biasanya batas minimal yang ditolerir adalah sebesar 80\% (Ranganathan \& Lagarde, 2012; Zulkhibri, 2016) dari total yang ditetapkan oleh otoritas kesehatan suatu negara, untuk Indonesia mengikuti persyaratan yang telah ditetapkan oleh kementerian kesehatan (Bappenas, 2008).

Para pendamping mawquf 'alaib juga memiliki peran dalam memberikan edukasi kepada penerima untuk mematuhi menerapkan perilaku hidup bersih dan sehat terutama berkenaan dengan sanitasi dan pola konsumsi yang sehat sehingga terhindar dari masalah stunting. Selain itu para pendamping memiliki peran sentral dalam memonitori proses pendistribusian bantuan dana wakaf, dana wakaf harus betul-betul digunakan oleh penerima sesuai dengan peruntukan yang telah ditetapkan sebelumnya yaitu untuk kebutuhan gizi dan nutrisi serta untuk kebutuhan fasilitas sanitasi. Dana tersebut tidak boleh digunakan untuk kebutuhan yang tidak esensial seperti membeli rokok dan kebutuhan non primer lainnya (Bappenas, 2008).

Dalam pelaksanaannya para mauquf 'alaih akan dikeluarkan dari kepesertaan apabila tidak lagi memiliki komponen miskin, hamil dan memiliki balita. Atau status ekonomi yang bersangkutan sudah tidak masuk dalam kategori miskin lagi. Selain itu status kepesertaan juga bisa dihilangkan apabila para penerima bantuan tidak berkomitmen untuk mematuhi semua persyaratan yang telah ditetapkan sebelumnya (Ranganathan \& Lagarde, 2012).

\section{Kesimpulan}

Stunting merupakan masalah kekurangan gizi dan nutrisi yang dialami oleh balita yang menyebabkan balita tersebut mengalami pertumbuhan yang tidak wajar dan proporsional. Masalah stunting tidak boleh hanya dimaknai sebagai problem tumbuh kembang balita saja tetapi merupakan representasi dari problematika kemiskinan, ketimpangan dan sanitasi yang buruk. Stunting adalah problematika kualitas sumber daya manusia penerus masa depan bangsa, bukti empiris pada tataran Internasional menunjukkan bahwa stunting dapat menghambat pertumbuhan ekonomi dan menurunkan produktivitas pasar kerja, sehingga mengakibatkan menyebabkan penurunan GDP (Gross Domestic Products) (Saputri \& Tumangger, 2019). Generasi yang tumbuh optimal alias tidak stunting memiliki tingkat kecerdasan yang lebih baik, akan memberikan daya saing yang baik dibidang pembangunan dan ekonomi (Cameron et al., 2021) Indonesia merupakan salah satu negara yang mengalami krisis stunting sehingga membutuhkan langkah konkret untuk mengatasi problematika tersebut. Salah satu solusinya adalah dengan inovasi pada pendistribusian dana wakaf menggunakan skema Conditional Cash Transfers (CCTs) karena skema ini secara empiris berhasil menyelesaikan 
berbagai permasalahan sosial di berbagai negara termasuk permasalahan stunting. Pendistribusian dana wakaf menggunakan CCTs dilakukan dengan memperhatikan prinsip dasar dalam implementasi skema CCTs berupa persyaratan kewajiban mauquf alaib untuk memeriksakan kondisi kehamilan dan balita pada fasilitas kesehatan, target peserta penerima bantuan adalah yang berasal dari keluarga miskin dan memiliki anggota rumah tangga yang sedang hamil dan balita, pemberian dana wakaf dalam bentuk nutrisi dan penyediaan fasilitas sanitasi yang baik. Selain itu dibutuhkan seorang pendamping (supervisor) untuk mengawasi bisnis proses CCTs.

\section{Referensi}

Abdullah, M. (2018). Waqf, Sustainable Development Goals (SDGs) and maqasid al-shariah. International Journal of Social Economics, 45(1), 158-172. https://doi.org/10.1108/IJSE-102016-0295

Aryastami, N. K., \& Tarigan, I. (2017). Kajian Kebijakan dan Penanggulangan Masalah Gizi Stunting di Indonesia. Bul. Penelit. Kesehat, 45, 233-240.

Atabik, A. (2014). Manajemen pengelolaan wakaf tunai di indonesia. Ziswaf: Jurnal Zakat Dan Wakaf, 1(1), 82-107.

Attanasio, O., Fitzsimons, E., Gomez, A., Meghir, C., Mesnard, A., \& GutiéRrez, M. I. (2010). Children's schooling and work in the presence of a conditional cash transfer program in rural Colombia. Economic Development and Cultural Change, 58(2), 181-210. https://doi.org/10.1086/648188

Bappenas. (2008). Program Keluarga Harapan (PKH): Two Case Studies on Implementing the Indonesian Conditional Cash Transfer Program. Jakarta. Retrieved from http://www.bappenas.go.id/getfile-server/node/7315

Barham, T., \& Rowberry, J. (2013). Living longer : The effect of the Mexican conditional cash transfer program on elderly mortality ir. Journal of Development Economics, 105, 226-236. https://doi.org/10.1016/j.jdeveco.2013.08.002

Cacciamali, M. C., Tatei, F., \& Batista, N. F. (2010). Impactos do Programa Bolsa Família federal sobre o trabalho infantil e a frequência escolar. Revista de Economia Contemporânea, 14(2), 269-301. https://doi.org/10.1590/s1415-98482010000200003

Cameron, L., Chase, C., Haque, S., Joseph, G., Pinto, R., \& Wang, Q. (2021). Childhood stunting and cognitive effects of water and sanitation in Indonesia. Economics and Human Biology, 40, 100944. https://doi.org/10.1016/j.ehb.2020.100944

Charness, G. B., Gneezy, U., Org, E., \& Charness, G. (2008). Incentives to Exercise: UC Santa Barbara Departmental Working Papers. Retrieved from https://escholarship.org/uc/item/3tc3j5x7

Darus, F., Ahmad Shukri, N. H., Yusoff, H., Ramli, A., Mohamed Zain, M., \& Abu Bakar, N. A. (2017). Empowering social responsibility of Islamic organizations through Waqf. Research in International Business and Finance, 42, 959-965. https://doi.org/10.1016/j.ribaf.2017.07.030

Dubois, P., de Janvry, A., \& Sadoulet, E. (2012). Effects on school enrollment and performance of a conditional cash transfer program in Mexico. Journal of Labor Economics, 30(3), 555-589. https://doi.org/10.1086/664928

Fernald, L. C., Gertler, P. J., \& Neufeld, L. M. (2008). Role of cash in conditional cash transfer programmes for child health, growth, and development: an analysis of Mexico's 
Oportunidades. The Lancet, 371(9615), 828-837. https://doi.org/10.1016/S01406736(08)60382-7

Ferreira, F. H. G., Filmer, D., \& Schady, N. (2018). OWN AND SIBLING EFFECTS OF CONDITIONAL CASH TRANSFER PROGRAMS : THEORY AND EVIDENCE FROM CAMBODIA 1 Own and Sibling Effect of Conditional Cash Transfer Program: Theory and Evidence from Cambodia. Research on Economic Inequality, 25, 259-298. https://doi.org/10.1108/S1049-258520170000025008

Fishbein, M., \& Ajzen, I. (2005). The Influence of Attitudes on Behavior. The Handbook of Attitudes, (May), 173-222. Retrieved from http:/ /books.google.com/books?hl=en\&lr=\&id=qoJ5AgAAQBAJ\&oi=fnd\&pg=PA1 $73 \& \mathrm{dq}=$ The + Influence + of + Attitudes + on + Behavior\&ots $=I 3 v$ mnYWDce\&sig $=1$ ASA milgqxpMyNlnszyUROK82Fg\%0Ahttp://books.google.com/books?hl=en\&lr=\&id=q oJ 5 AgAAQBAJ\&oi $=$ fnd $\& p g=$ PA173\&dq $=$ The + influence + of +

Hamber, N. M., \& Haneef, M. A. (2017). Waqf-Based Social Micro Venture Fund : A Proposal for the Malay-Muslim Community in Singapore Norliana Mohammad Hamber. JKAU: Islamic Econ, 30(1), 37-60.

Haneef, M. A., Muhammad, A. D., Pramanik, A. H., \& Mohammed, M. O. (2014). Integrated waqf based islamic microfinance model (IWIMM) for poverty alleviation in OIC member countries. Middle - East Journal of Scientific Research, 19(2), 286-298. https://doi.org/10.5829/idosi.mejsr.2014.19.2.12565

Kabeer, N., \& Waddington, H. (2015). Economic impacts of conditional cash transfer programmes: a systematic review and meta-analysis. Journal of Development Effectiveness, 7(3), 290-303. https://doi.org/10.1080/19439342.2015.1068833

Khan, M. T. (2015). Development of Human Capital Through Institution of Islamic Waqf. International Journal of Information, Business and Management, 7(3), 41.

Kusuma, D., Thabrany, H., Hidayat, B., \& Mcconnell, M. (2017). New Evidence on the Impact of Large-scale Conditional Cash Transfers on Child Vaccination Rates : The Case of a Clustered-Randomized Trial in Indonesia. World Development, 98, 497-505. https://doi.org/10.1016/j.worlddev.2017.05.007

Mariano, S. (2020). Conditional cash transfers, empowerment and female autonomy : care and paid work in the Bolsa Fam a lia programme, Brazil. 40(11), 1491-1507. https://doi.org/10.1108/IJSSP03-2020-0093

Mill, T. M., Macours, K., Maluccio, J. A., \& Tejerina, L. (2020). Experimental long-term effects of early-childhood and school-age exposure to a conditional cash transfer program is. Journal of Development Economics, 143(June 2019), 1-20. https://doi.org/10.1016/j.jdeveco.2019.102385

Moniaga, J. V., Ohyver, M., Siregar, J., \& Yauwito, P. H. (2019). Map-type modelling and analysis of children stunting case data in Indonesia with interactive multimedia method. Procedia Computer Science, 157, 530-536. https://doi.org/10.1016/j.procs.2019.09.010

Muhtar. (2020). Peran Pendamping Program Keluarga Harapan Dalam Rehabilitasi Rumah Tidak Layak Huni di Kabupaten Magetan. Sosio Konsepsia, 10(1), 45-54.

Noordin, N. H., Haron, S. N., \& Kassim, S. (n.d.). Developing a comprehensive performance measurement system for waqf institutions. International Journal of Social Economics. https://doi.org/10.1108/IJSE-09-2015-0257 
Norbert Schady, \& Maria Caridad Araujo. (2008). Cash Transfers, Conditions, and School Enrollment in Ecuador. Economia, 8(2), 43-70. https://doi.org/10.1353/eco.0.0004

Nur Cahyadi, Hanna, R., Olken, B. A., Prima, R. A., Satriawan, E., \& Syamsulhakim, E. (2018). Cumulative Impact of Conditional Cash Transfer Programs: Experimental Evidence From Indonesia. In National Bereau of Economic Research Working Paper Series 24670 (No. 24670; Vol. 24670). Massachussets.

Nurwan, T. W., \& Hasan, H. (2020). Keberhasilan PKH ditinjau dalam kaitannya dengan Keterampilan Pendamping dan Partisipasi KPM: Studi di Sijunjung Sumatera Barat. Sosio Konsepsia, 10(1), 1-13. https://doi.org/10.33007/ska.v10i1.2035

Oliveira, P. R. De, Kassouf, A. L., \& Aquino, J. M. De. (2017). Cash transfers to the elderly and its spillover effects Evidences from a non-contributory program in Brazil. 44(2), 183-205. https://doi.org/10.1108/JES-04-2015-0059

Pescarini, J. M., Williamson, E., Nery, J. S., Ramond, A., Ichihara, M. Y., Fiaccone, R. L., ... Barreto, M. L. (2020). Effect of a conditional cash transfer programme on leprosy treatment adherence and cure in patients from the nationwide 100 Million Brazilian Cohort: a quasi-experimental study. The Lancet Infectious Diseases, 20(5), 618-627. https://doi.org/10.1016/S1473-3099(19)30624-3

Rahman, M. M., \& Pallikadavath, S. (2018). How much do conditional cash transfers increase the utilization of maternal and child health care services? New evidence from Janani Suraksha Yojana in India. Economics and Human Biology, 31, 164-183. https://doi.org/10.1016/j.ehb.2018.08.007

Ranganathan, M., \& Lagarde, M. (2012). Promoting healthy behaviours and improving health outcomes in low and middle income countries: A review of the impact of conditional cash transfer programmes. Preventive Medicine, 55, S95-S105. https://doi.org/10.1016/j.ypmed.2011.11.015

Ravallion, M., \& Wodon, Q. (2000). Does child labour displace schooling? Evidence on behavioural responses to an enrollment subsidy. Economic Journal, 110(462), 158-175. https://doi.org/10.1111/1468-0297.00527

Rawlings, L. B., \& Rubio, G. M. (2005). Evaluating the impact of conditional cash transfer programs. World Bank Research Observer, 20(1), 29-55. https://doi.org/10.1093/wbro/lki001

Rizal, M. F., \& van Doorslaer, E. (2019). Explaining the fall of socioeconomic inequality in childhood stunting in Indonesia. SSM - Population Health, 9, 100469. https://doi.org/10.1016/j.ssmph.2019.100469

Santana, P., Pais, M., \& Silva, F. D. F. (2013). The influence of Bolsa Familia conditional cash transfer program on child labor in Brazil. (2000). https:// doi.org/10.1108/IJSE-02-2015-0038

Sanusi, S., \& Shafiai, M. H. M. (2015). The management of cash waqf: Toward socio-economic development of muslims in Malaysia. Jurnal Pengurusan, 43, 3-12. https://doi.org/10.17576/2015-43-01

Saputri, R. A., \& Tumangger, J. (2019). Hulu-Hilir Penanggulangan Stunting Di Indonesia. Journal of Political Issues, 1(1), 1-9. https://doi.org/10.33019/jpi.v1i1.2

Schultz, T. P. (2004). School Subsidies for the Poor: Evaluating the Mexican Progresa Poverty Program. Journal of Development Economics, 74(1), 199-250.

Seprillina, L., Qurrata, V. A., Narmaditya, B. S., \& Hussain, N. E. B. (2019). The Effectiveness 
Productive Waqf as a Social Welfare Development Through Community Empowering: A Case in Islamic Hospital Foundation Malang. Review of Integrative Business and Economics Research, 9(3), 67-74.

Skoufias, E., \& Parker, S. W. (2001). Conditional Cash Transfers and Their Impact on Child Work and Schooling: Evidence from the PROGRESA Program in Mexico. Economia, 2(1), 45-86. https://doi.org/10.1353/eco.2001.0016

Soeherman, B. (2019). Fun Research: Penelitian Kualitatif dengan design Thingking (Ebook). Jakarta: PT. Elex Media Komputindo.

Son, H. H. (2008). Conditional Cash Transfer Programs: An Effective Tool for Poverty Alleviation? In ADB Economics and Research Department Policy Brief Series No. 51. Manila: Asian Development Bank. Retrieved http://www.ncbi.nlm.nih.gov/pubmed/21122965

Sukmana, R. (2020). Critical assessment of Islamic endowment funds (Waqf) literature: lesson for government and future directions. Heliyon, 6(10), e05074. https://doi.org/10.1016/j.heliyon.2020.e05074

Tight, M. (2019). Starting Documentary Research in: Documentary Research in the Social Sciences (Online (E-). 55 City Road: SAGE Publication.

Usman, N. (2014). Pengelolaan Wakaf Produktif Untuk Kesehatan. Muaddib, 04(02), 1-20.

Volpp, K. G., John, L. K., Troxel, A. B., Norton, L., Fassbender, J., \& Loewenstein, G. (2008). Financial Incentive-Based Approaches for Weight Loss. JAMA: The Journal of the American Medical Association, 300(22), 2631-2637. Retrieved from http://jama.jamanetwork.com/article.aspx?doi=10.1001/jama.2008.804\%5Cnpapers2:/ /publication/doi/10.1001/jama.2008.804

Volpp, K. G., Levy, A. G., Asch, D. A., Berlin, J. A., Murphy, J. J., Gomez, A., ... Lerman, C. (2009). A randomized controlled trial of financial incentives for smoking cessation. The New England Journal of Medicine Special, 15(1), 12-18. https://doi.org/10.1158/10559965.EPI-05-0314

Waziri, M., Zubir, A., Ibrahim, B., Bin, Z., \& Bin, Z. (2020). Investigating the empirical relationship between government intervention programs and poverty alleviation : a case of Nigeria. 36(4), 323-338. https://doi.org/10.1108/JEAS-06-2019-0060

Zakari, M. S. (2015). Efficiency and effectiveness of waqf institutions in Malaysia: Toward financial sustainability. Bloomsbury Qatar Foundation Journals, 43-53.

Zulkhibri, M. (2016). The relevance of conditional cash transfers in developing economy : the case of Muslim countries. 43(12), 1513-1538. https://doi.org/10.1108/IJSE-06-2014-0116 
-- This page intentionally left blank --

124 | Al-Awqaf: Jurnal Wakaf dan Ekonomi Islam, Vol. 13, No. 2, Tahun 2020 